\title{
OSJEČKO DRUŠTVO OD 1868. DO 1914.
}

Tomislav Romolić, Petra Sršić Filozofski fakultet Osijek Odsjek za povijest

Stručni rad

Primljeno: 8. 2. 2019.

Prihvaćeno: 13. 10. 2019.

romotom7@gmail.com, petrasrsic134@gmail.com

\begin{abstract}
U ovom članku prikazani su i analizirani različiti aspekti osječkoga društva u razdoblju od potpisivanja Hrvatsko-ugarske nagodbe 1868. godine do početka Prvoga svjetskog rata 1914. godine. Nakon kratkoga pregleda bitnijih infrastrukturnih i građevinskih projekata u navedenom razdoblju, autori ostatak rada posvećuju pregledu društvenih slojeva na području grada Osijeka. Posebna pažnja posvećena je radničkoj klasi koja je, zbog industrijskog razvoja grada u drugoj polovici 19. stoljeća, postala jedan od najznačajnijih faktora osječkoga društva. Marginalne skupine, posebno Židovi, Romi, prostitutke i prosjaci, posebno su istaknuti. Spomenut je i multietnički i višejezični karakter grada kojim je Osijek razvijao svoj identitet. Konačno, članak je kratkim navođenjem novoosnovanih društava i udruženja prikazao rastuće građansko djelovanje i aktivizam. Također, isticanjem društveno-kulturnih aktivnosti građana svih slojeva pokazuje se sva živost Osijeka u ovom periodu.
\end{abstract}

Ključne riječi: Osijek, društvo, modernizacija, društveni slojevi, radništvo, marginalne skupine, etničke značajke, udruge, okupljališta

\section{Uvod}

Razdoblje dugoga 19. stoljeća obilježeno je iznimnim promjenama u svim sferama ljudskoga života, izazvanim industrijskim te socijalno-političkim i ostalim revolucijama. Takve promjene zahvatile su i hrvatske zemlje u drugoj polovici 19. stoljeća. Ukidanjem feudalnih odnosa u revoluciji 1848./49., napravio se prvi korak prema društveno-gospodarskom napretku. Međutim, nerazvijeno unutrašnje tržište te ovisnost o bečkoj i budimpeštanskoj financijskoj politici bile su velike zapreke širenju manufakturnoga poduzetništva u hrvatskim zemljama. ${ }^{1}$ Hrvatsko-ugarska nagodba, potpisana 1868. godine, utvrdila je bolje uvjete za razvoj hrvatskoga gospodarstva. Unatoč tomu, gospodarska kriza nastala krahom bečke burze 1873. godine samo je produbila probleme u razvoju industrije u Hrvatskoj. Ti negativni

1 Igor Karaman, Privreda i društvo Hrvatske u 19. stoljeću, Zagreb 1972., 2. 
trendovi promijenit će se u zadnjih tridesetak godina prije Prvoga svjetskog rata. Kao i u ostatku svijeta, gdje je industrijski temeljeno gospodarstvo živnulo, tako i u Hrvatskoj i Slavoniji paralelno dolazi do društvenih promjena. Na temelju društveno-urbanoga razvoja grada Osijeka u periodu od potpisivanja nagodbe do razdoblja prije Prvoga svjetskog rata, ovaj rad pokušat će odrediti odnose u društvu koje su zahvatile navedene promjene. Kako bismo došli do pregleda društva, prvo ćemo objasniti vezu između društva i okoliša te prikazati urbani razvoj grada. Zatim ćemo osječko društvo podijeliti u slojeve kako bi se svakom dijelu društva pristupilo zasebno, te prikazalo njihovu ulogu u razvoju gradskoga života. Bitno je istaknuti i etnički element koji je svakako igrao značajnu ulogu u multikulturalnom identitetu grada. Zato je potrebno navesti i one koji su se nalazili na rubu društva, kako bismo objedinili sve društvene položaje prisutne u gradu. Konačno, popratit će se osnivanje i djelovanje najvažnijih društava i udruga koje naglašavaju onodobni urbani „štih“ grada. Budući da je Osijek u navedenom razdoblju bio važno vojno središte, ${ }^{2}$ potrebno je istaknuti da se ovaj rad bazira na proučavanju civilnoga stanovništva zbog činjenice što bi proširivanje istraživačkoga pitanja povećalo, i ovako veliki, opseg rada. Cilj rada jest objediniti urbani i društveni identitet Osijeka u razdoblju od 1868. do 1914. godine kako bi se prikazao razvoj grada u jedno moderno urbano središte. Dostupna je opsežna literatura o Osijeku u navedenomu razdoblju te će se za potrebe ovoga rada koristiti knjige i članci od kojih bismo istaknuli Povijest Osijeka: Sv. 2: Od turskog do suvremenog Osijeka, urednika Ive Mažurana te brojne radove Zlate Živaković-Kerže i Luke Pejića.

\section{Društvo i prostor}

Da bismo adekvatno objasnili osječko društvo u navedenom razdoblju, potrebno je definirati pojam društva te ga smjestiti u prostor koji je ono naseljavalo. U svojoj knjizi, Društva, T. Parsons društvo sažeto definira kao tip društvenoga sistema koji postiže najviši stupanj samodovoljnosti kao sistem u odnosu na svoje okruženje. ${ }^{3}$ Nadalje, strukturirani normativni poredak jezgra je društva kao sistema te prihvaćanje

2 Vesna Božić-Drljača i Danijel Jelaš, Život u Osijeku u okolnostima Prvog svjetskog rata, Osijek 2014., 9.: U Osijeku su bile stacionirane: 78. pješačka pukovnija, 28. domobranska pješačka pukovnija, dijelovi 38. topničke te 12. ulanske pukovnije 
i poštivanje toga poretka određuje pripadnost pojedinaca određenom društvu. ${ }^{4}$ Prema tome, svaki član društvene zajednice ima propisan status, prava i dužnosti, a da bi ta zajednica preživjela i razvijala se, potrebno je održavati i zajedničku kulturnu orijentaciju, koju u osnovnom obliku dijele svi pripadnici kao osnovu svoga socijalnog identiteta. ${ }^{5}$ Svako društvo nastanjuje određeno područje, fizički okoliš koji predstavlja izvor materijalnih resursa koje može iskorištavati. Raspodjela pristupa tim resursima određuje se prema ekonomskim interesima različitih skupina ljudi koji čine to društvo. ${ }^{6}$ Ukratko, ljudsko djelovanje utječe na prostor koji istodobno usmjerava i ograničava to djelovanje. U ovom radu, promatrano je društvo prostorne jedinice grada Osijeka. Smješten na periferiji Austro-Ugarske Monarhije, Osijek krajem 19. stoljeća doživljava značajan ekonomski uzlet u kojem će se stvoriti uvjeti za preobrazbu društva iz tadašnjega stupnja razvoja u moderno građansko društvo. ${ }^{7}$ Ta je preobrazba utjecala na razvoj i izgled grada koji će detaljnije biti opisan u idućem poglavlju.

\section{Urbani razvoj i modernizacija grada}

Prilikom opisivanja urbanoga razvoja Osijeka važno je osvrnuti se na stanje u hrvatskim pokrajinama i spomenuti da je udio gradskoga stanovništva 1910. godine iznosio 8.5\%, dok je gradova iznad 10000 stanovnika na području Hrvatske i Slavonije bilo samo šest, ${ }^{8}$ te da je Osijek bio među njima. Hrvatsko-slavonsko društvo u razdoblju između Nagodbe i Prvoga svjetskog rata obilježio je usporeni napredak ka građanskom društvu, dok obrtništvo i trgovina ostaju osnove njegova razvitka. ${ }^{9}$ Unatoč tomu, u hrvatskim zemljama bilježi se blagi porast industrije te stvaranje industrijskih poduzetnika i njemu podređenoga radništva, što uzrokuje određene promjene u društvenom i socijalnom životu zemlje. Rastuća industrija uvjetovala je veću mobilnost stanovništva te je jedan od ciljeva pri razvoju Osijeka u ovomu periodu bilo spajanje tri urbana nukleusa (Gornji grad, Tvrđa i Donji grad) u jednu urbanu cjelinu. Zbog povlačenja vojne komande iz Tvrđe ona gubi na važnosti, čime dolazi do procvata Gornjega grada koji postaje admini-

4 Parsons, Društva, 21.

5 Isto.

6 Isto, 160.

7 Mirjana Gross i Agnesa Szabo, Prema hrvatskome građanskom društvu, 19. Zagreb, 1992.

8 Karaman, Privreda i društvo, 257-258.

9 Isto, 265. 
strativni, privredni i kulturni centar Osijeka. ${ }^{10}$ Krajem stoljeća dolazi do procvata izgradnje na prostoru između Tvrđe i Gornjega grada. Urbanistički plan bio je pomaknuti centar grada između tih dviju gradskih četvrti. To pokazuje i Regulatorna osnova za grad Osijek, izrađena 1912. godine (Slika 1). Na regulatornoj je osnovi vidljiv plan povezivanja svih dijelova grada u jedinstveni gradski organizam, ali njezinu provedbu onemogućuje Prvi svjetski rat, tek nakon kojega je ostvaren dio predviđenih planova. ${ }^{11}$ Razvoj Osijeka pratila je izgradnja brojnih novih stambeno-poslovnih, administrativnih i kulturno-umjetničkih zgrada. Urbani planeri mnogobrojnim su projektima u drugoj polovici 19. i početkom 20. stoljeća pridonijeli ugledu Osijeka u Monarhiji. ${ }^{12}$ Već spomenutim spajanjem triju urbanih cjelina u jednu, 1881. godine dolazi do nastanka ceste koja je pratila današnju Europsku aveniju (tadašnja Čavrakova ulica), a trebala je spojiti Gornji grad s Tvrđom i Donjim gradom. Određena je za glavnu gradsku ulicu te će svoj poznati secesijski niz zgrada dobiti između 1904. i 1906. godine.

Reputacija Osijeka kao industrijskoga grada stvorena je upravo u ovom razdoblju. Otvoren je veliki broj tvornica, radionica i mlinova te se mogu istaknuti tvornice stakla, pokućstva, kože, čokolade, lana i konoplje, šećera, šibica, sapuna, opeke i crijepa, gospodarskih strojeva, rublja, itd. ${ }^{13}$ Djelovanje Trgovačko-obrtničke komore u Osijeku, osnovane 1853., važno je i za razdoblje od 1868. godine, zato što je poticala razvoj grada i projekte poput osnivanja prvoga poštanskog ureda, početka regulacije rijeke Drave i izgradnje željezničke pruge. ${ }^{14}$

10 Stjepan Sršan, Povijest Osijeka, Osijek 1996., 75., Zlata Živaković-Kerže, Urbanizacija i promet, Osijek 1999., 78-80.

11 Tihomir Jukić i Srečko Pegan, Prostorni i urbanistički razvoj Osijeka : kritika i prijedlozi. Zagreb 2005., 30.

12 Isto, 30-31.: Zgrada osječkoga kasina i kazališta, zgrada gornjogradske pučke učionice, hotel Europa, palača Trgovačko-obrtničke komore za Slavoniju itd.

13 Božo Plevnik, Stari Osijek, Osijek 1999., 136., Zlata Živaković-Kerže, S tradicionalnih na nove puteve: trgovina, obrt, industrija i bankarske ustanove grada Osijeka na prijelazu stoljeća od godine 1868. do 1918., Osijek 1999., 203-204.

14 Plevnik, Stari Osijek, 147. 


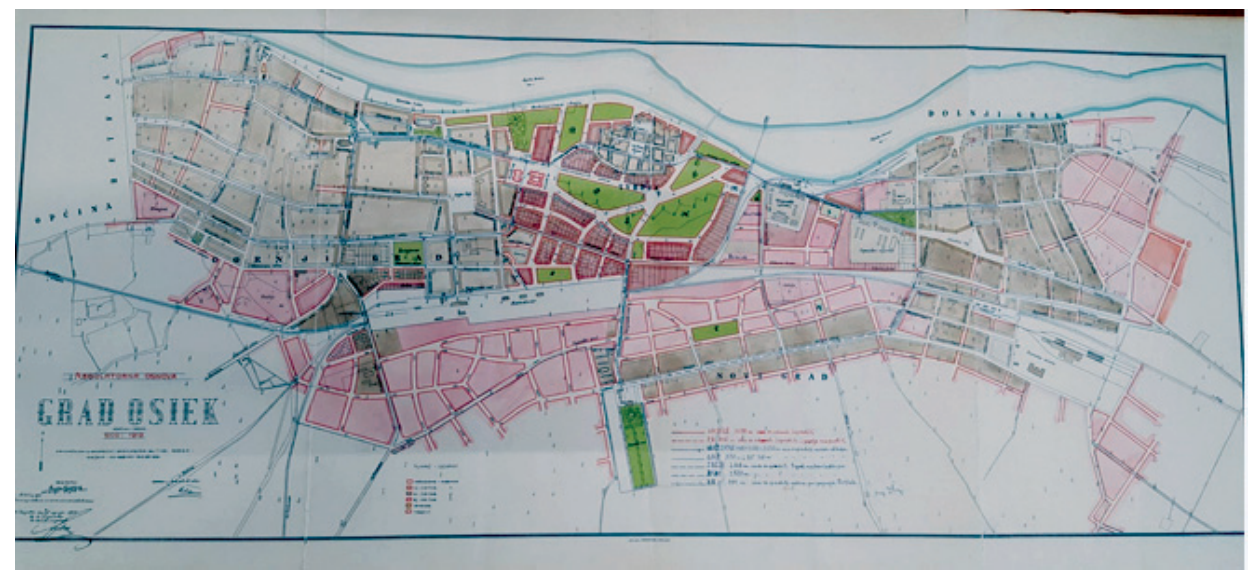

Slika 1. Karta i urbanistički plan (regulatorna osnova) Osijeka iz 1912. godine ${ }^{15}$

Kada govorimo o prometnoj infrastrukturi grada, važna je 1869. godina kada je Osijek spojen na tada već razgranatu mrežu željeznica Monarhije. Željeznica je povezivala Osijek s Vilanyjem u mađarskoj Baranji, te Segedinom, a pruga je išla preko Dalja i Subotice. Nadalje, 1893. godine u promet je puštena druga dionica Osijek - Našice, 1905. godine Osijek spojen je s Bosnom preko Đakova i Vrpolja, a posljednja predratna veza ostvarena je 1910. godine s Vinkovcima. ${ }^{16}$ Gradski javni prijevoz činio je do 1884. godine tzv. omnibus, koji je imao oblik komode, a vukao ga je konj. ${ }^{17}$ Godine 1884. izgrađen je konjski tramvaj, prvi u jugoistočnoj Europi (prije Sarajeva 1885. i Zagreba 1891.). Idućih godina dolazi do širenja tramvajske mreže po gradu. Konjski tramvaji vozili su sve do 1926. godine kada ih mijenja električni tramvaj. Godine 1911. uvedeni su i gradski autobusi, kao konkurencija dioničkom društvu za konjsku željeznicu. ${ }^{18}$

Brojni građevinski projekti na području grada bili su djelo uglednoga osječkog arhitekta njemačko-židovskog porijekla Viktora Axmanna, koji je 1911. projektirao, a godinu dana kasnije dovršio, secesijsku zgradu kina Urania. Od ostalih projekata koje je zahvatila sveopća infrastrukturna modernizacija bila je vodoopskrba koja je predstavljala veliki problem gradu. Voda iz rijeke Drave bila je sve zagađenija zbog širenja industrijskih postrojenja, a taj se problem riješio tek 1894. godine kada je grad omogućio opskrbu vodom iz dubinskih bunara. ${ }^{19}$

15 HR-DAOS-495/IV, sig.1.5, mapa 48, Planovi grada

16 Sršan, Povijest Osijeka, 77-78.

17 Vilma Vukelić, Tragovi prošlosti, Zagreb 1994., 13.

18 Sršan, Povijest Osijeka, 78.

19 Isto, 79. 


\section{Osječko društvo}

Budući da je u prošlom poglavlju opisan opći pregled urbanoga razvoja Osijeka, rad se nastavlja s pregledom društva koje je nastanjivalo grad. Ljudsko biće, kao nositelj djelovanja, uči i razvija se u kontekstu određenoga sustava kulture. Tako se oblikuje naučeni sistem ponašanja pojedinca koji ima zajedničke crte sa sistemom ponašanja drugih osoba, primjerice jezik kojim govori ili mjesta koja posjećuje. Nadalje, osobe koje dijele određene karakteristike sistema ponašanja u izvjesnom su smislu jedinstvene te je njihov vlastiti sistem jedinstvena varijanta te kulture i njezinih konkretnih obrazaca djelovanja. ${ }^{20}$ Moguće je, prema tome, podijeliti društvo na različite grupe pojedinaca koji dijele sličan sistem ponašanja, odnosno na slojeve, prema karakteristikama koji ih opisuju.

\section{Viši slojevi}

U općoj društvenoj hijerarhijskoj piramidi najviši sloj činili su najbogatiji i najutjecajniji građani. Bogati trgovci, industrijalci, odvjetnici, osobe na visokim položajima u gradskoj i županijskoj upravi pa i neki plemići, krojili su osječku političku i društvenu scenu. Budući da su u manjini, ukratko ćemo spomenuti plemićku obitelj Pejačević, čiji se dvorac izgrađen početkom 19. stoljeća i danas može vidjeti u Retfali. Posjedima u Slavoniji i Srijemu upravljao je Petar Pejačević (1804. 1887.), koji je svojedobno obnašao dužnost velikoga župana Križevačke županije, zatim velikoga župana Virovitičke županije, velikoga župana Srijemske županije, zastupnika u Hrvatskom saboru, itd. ${ }^{21} \mathrm{~S}$ Petrovim sinovima izumire rumsko-retfalačka loza velikaške obitelji Pejačević te se njihovi posjedi početkom 20. stoljeća dijele i rasprodaju. ${ }^{22}$

Imovinski status višega sloja omogućio im je lagodan život. Kuće najbogatijega sloja nalazile su se u Gornjem gradu, građene 1870-tih godina u stilu historicizma, te u već spomenutoj Europskoj aveniji

20 Talcott, Društva, 17.

21 https://hr.wikipedia.org/wiki / Peja\%C4\%8Devi\%C4\%87i\#-_Rumskoretfala\%C4\%8Dki (17. 4. 2019.): Bio je još i ministar bez lisnice za Hrvatsku, Slavoniju i Dalmaciju, te carski i kraljevski komornik.

22 Đorđe Bošković i Jasminka Najcer Sabljak, „Likovna i rukopisna ostavština Ladislava grofa Pejačevića iz Retfale i Rume“, Scrinia Slavonica 18 (2018), br. 1: 130-131.: Smrću Josipa grofa Pejačevića 1787. godine i podjelom njegovih posjeda između sinova započeo je razvoj triju obiteljskih grana: našičke, virovitičke i rumsko-retfalačke. Potonju je utemeljio Josipov sin Žigmund grof Pejačević (1741. - 1806.) 
gdje su izgrađene secesijske kuće uglednih odvjetnika, veleposjednika i industrijalaca. ${ }^{23}$ Pripadnici osječke elite stanovali su u udobno građenim dvokatnicama, izgrađenim po nacrtima i u izvedbi stručnjaka, arhitekata i graditelja poput Teodora Sterna, Aloisa Flanbacha, Josipa pl. Van-caša, Karla Klausnera i drugih. ${ }^{24}$ U oblikovanju prvih modernih građanskih kuća nezaobilazni su industrijalci i trgovci iz obitelji Reisner, Šeper, Kaiser, Povischil i Kraus.

\section{Ugledni građani i industrijalci}

Iza impresivnoga razvoja grada u ovom razdoblju kriju se ljudi koji su oblikovali ne samo njegov izgled, nego i duh. Među najzaslužnijima svakako je Josip Juraj Strossmayer, čija je kulturna i politička djelatnost nadišla osječke i prešla u nacionalne okvire. Kada govorimo o djelovanju u Osijeku, bio je među najzaslužnijima za izgradnju osječke konkatedrale sv. Petra i Pavla, koju je osobno blagoslovio 1900. godine, a čija je gradnja završena dvije godine ranije. ${ }^{25}$ Međutim, Vukelić navodi da odnos Strossmayera i Osječana nije bio posve srdačan te ga možemo okarakterizirati suzdržanim poradi različitih političkih uvjerenja vodećih Osječana i Strossmayera. ${ }^{26} \mathrm{Na}$ području industrije, neizbježno je djelovanje Adama pl. Reisnera, čija je tvornica žigica simbolizirala uspon i modernizaciju osječke industrije. Bio je aktivan i u politici kao gradski zastupnik i dogradonačelnik, te je bio na čelu Trgovačkoobrtničke komore za Slavoniju od 1889. do 1893. godine. ${ }^{27}$ Potrebno je istaknuti i učenika Paje Kolarića, Franju Ksavera Kuhača, koji se, osim skladanjem, bavio i skupljanjem narodnih pjesama. Kuhač se smatra začetnikom hrvatske etnomuzikologije i glazbene historiografije. $\mathrm{Pu}$ tovao je po južnoslavenskim zemljama, što je rezultiralo brojnim člancima i zbirkama, od kojih se najznačajnije smatraju Južno-slovenske narodne popievke koje su sačinjavale oko 1600 narodnih napjeva. ${ }^{28}$

23 Jukić i Pegan, Prostorni i urbanistički razvoj, 30-31., Jelena Červenjak i Zlata Živaković-Kerže, „Modernizacijska kretanja i položaj žena u gradu Osijeku na prijelazu 19. u 20. stoljeće“, Scrinia Slavonica 14 (2014), br. 1: 1312.: Imale vodu iz slavine i engleske zahode Červenjak i Živaković-Kerže, „Modernizacijska kretanja“, 131., Jukić i Pegan, Prostorni $i$ urbanistički razvoj, 30-31.

25 http://essekeri.hr/strossmayer-josip-juraj.html (6. 4. 2019)

26 Vukelić, Tragovi prošlosti, 119.: Strossmayer je bio projugoslavenski orijentiran, čemu su se protivili većinski mađaronski i monarhistički raspoloženi Osječani

27 http://essekeri.hr/reisner-adam.html (6. 4. 2019)

28 http://www.enciklopedija.hr/natuknica.aspx?id=34445 (5. 4. 2019) 


\section{Srednji slojevi}

Pretpostavlja se da je stanovništvo, koje je na osječkoj društvenoj ljestvici zauzimalo zlatnu sredinu, živjelo u relativno dobrim materijalnim uvjetima. S obzirom na to da obrađena literatura ne pruža jasne informacije o materijalnome stanju ili svakodnevici određenih društvenih slojeva, možemo samo pretpostaviti kojim se zanimanjima bavio osječki srednji sloj stanovništva. Zlata Živaković-Kerže navodi da su pojedine grane obrta u vrlo teškom položaju, ${ }^{29}$ stoga obrtnike nije moguće kolektivno svrstati u srednji sloj, što potvrđuje i Vilma Vukelić koja ih naziva nižim slojevima stanovništva pri objašnjavanju koje su krčme posjećivali. ${ }^{30}$ Međutim, vlasnici ugostiteljskih objekata vjerojatno su pripadali srednjem sloju budući da je Osijek bio tranzitni i rastući industrijski grad te je jedan od najunosnijih poslova bio otvaranje krčme. ${ }^{31}$

Građani zaposleni u javnim službama i slobodnim zanimanjima, primjerice učitelji, profesori, zaposlenici visokih županijskih i gradskih službi i drugih administrativnih grana pripadali su srednjemu sloj. Važno je istaknuti da je u navedenom sektoru zvanja bilo zaposleno više od 7,50\% stanovništva od čega su dvije desetine žene. ${ }^{32}$ One su ponajviše radile kao učiteljice u pučkim školama te kao pomoćno osoblje u gradskim službama i zdravstvenim djelatnostima. Kao indikator pripadnosti srednjem sloju mogu poslužiti podaci o školovanju u Osijeku. Mažuran navodi da su Višu djevojačku školu, Veliku gimnaziju i Realnu gimnaziju većinom pohađala djeca obrtnika, sitnih trgovaca i činovnika, ${ }^{33}$ dok su djecu viših slojeva prije odlaska na studij van hrvatskih zemalja, podučavale guvernante te privatni učitelji i učiteljice ili su pohađali njemačku školu u Tvrđi, organiziranu za djecu austrijskih oficira. ${ }^{34}$ Moguće je u srednji sloj ubrojiti i ljekarnike i umjetnike, od kojih možemo izdvojiti Dimitrija Markovića, došljaka koji je u Osijeku proveo trideset godina i naslikao banove Ladislava Pejačevića 1880. i Teodora Pejačevića 1902. godine. ${ }^{35}$ Kao protutežu uspješnu Di-

29 Živaković-Kerže, $S$ tradicionalnih na nove puteve, 52.: Radnici zaposleni u građevnom obrtu pripadali su najsiromašnijem sloju žiteljstva

30 Vukelić, Tragovi prošlosti, 20-21.

31 Živaković Kerže, S tradicionalnih na nove puteve, 49.

32 Ive Mažuran et al., Povijest Osijeka: Sv. 2: Od turskog do suvremenog Osijeka, Osijek 1996., 162.

33 Isto, 194-196.

34 Červenjak i Živaković-Kerže, „Modernizacijska kretanja“, 135., Vukelić, Tragovi prošlosti, 61.

35 Oto Švajcer, „Pregled likovne umjetnosti u Osijeku u 19. stoljeću“, Osječki zbornik 22 (1979.), br. 1: 259. 
mitriju Markoviću možemo navesti rođenoga Osječanina Adolfa Waldingera, pejzažista koji je veći dio života proveo u lošim materijalnim prilikama. Štoviše, 1901. godine obratio se Gradskom poglavarstvu s molbom za bilo kakvu novčanu potporu. ${ }^{36}$ Srednjem sloju društva pripadala bi i baba Klara, vlasnica najvećega štanda na glavnom tvrđavskom trgu, koja je prodavala sve od kruha, peciva i suhih šljiva do nožića i češljeva. ${ }^{37}$

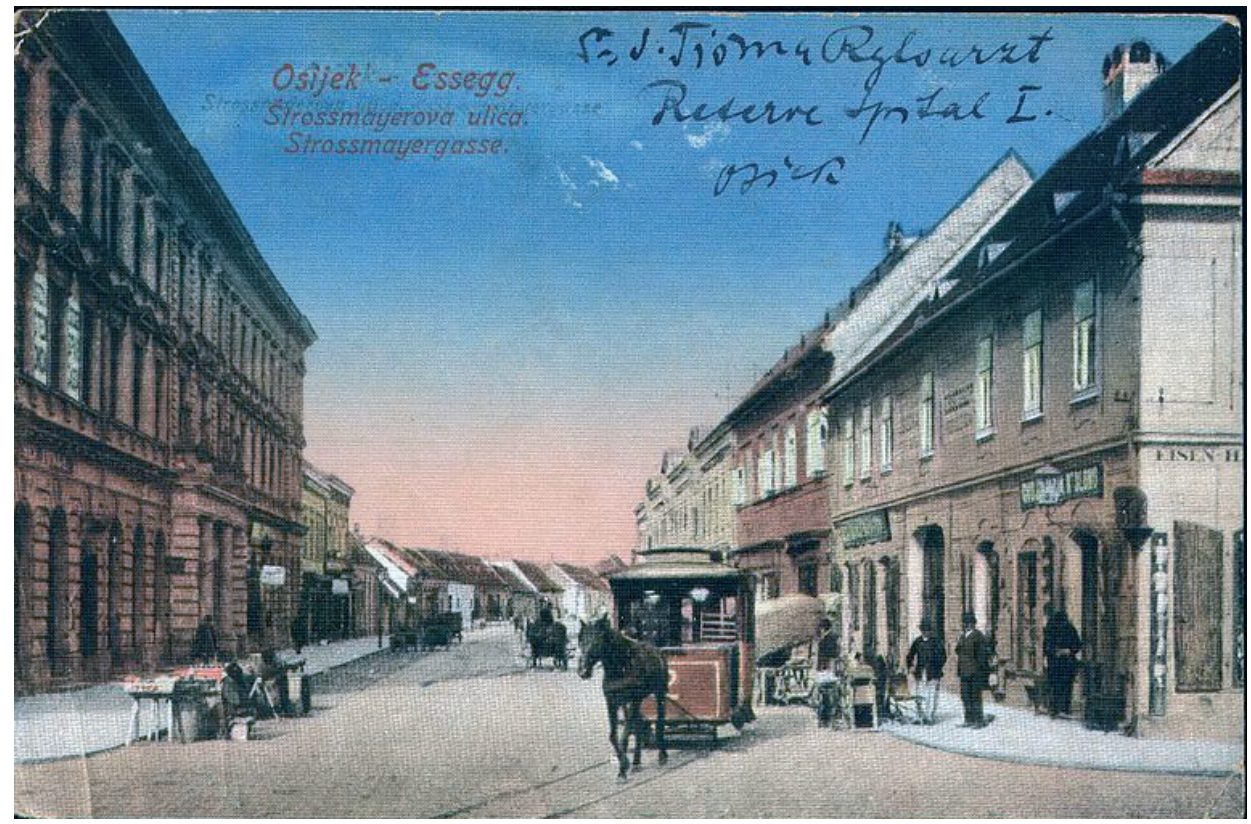

Slika 2. Strossmayerova ulica ${ }^{38}$

\section{Niži slojevi društva}

Na temelju raspodjele bogatstva najsiromašnijem dijelu zajednice pripadaju, kao i u većini tadašnjih zemalja, seljaci i radnici. Iako se sve do početka 20. stoljeća više od $10 \%$ osječkoga stanovništva bavilo poljodjelskim poslovima, ${ }^{39}$ opseg rada bio bi prevelik kada bismo detaljnije analizirali cje-

36 Švajcer, „Pregled likovne umjetnosti“, 257., Vukelić, Tragovi prošlosti, 168.

37 Marko Grgur Ivanković, „Tvrđa na fotografijama i razglednicama“, U: Tvrđa u Osijeku, ur. Denis Detling, Osijek 2017., 71.

38 http://rektorat.unios.hr/skup_2017/index.php?lah=1\&blt=9\&gal=stari_osijek (28. 4 . 2019.)

39 Mažuran et al., Od turskog do suvremenog Osijeka, 161.: Radi se o „posjednicima i zakupnicima većih i manjih površina obradivih zemljišta te njihovim pomoćnim radnicima“ 
lokupno stanovništvo koje se bavi određenom djelatnošću. S obzirom na to da do 1900. godine zaposleni radnici čine $18 \%$ stanovništva grada, a s obiteljima čak trećinu stanovništva $(31,9 \%),{ }^{40}$ te da je Osijek rastući industrijski grad, idući će se pododlomak opširnije baviti radništvom.

\section{Radništvo}

Hrvatsko-ugarska nagodba iz 1868. godine otvorila je put novim ulaganjima u osječke tvornice i projekte što rezultira polaganim rastom industrije, a time i zapošljavanjem većega broja radništva. Osijek je u razdoblju od 1868. do 1918. bio središte trgovine žitom, mlinske i drvne industrije. ${ }^{41}$ Božo Plevnik navodi da je 1863. godine Osijek imao 8 tvornica i manufaktura, 230 trgovačkih radnji i preko 1000 obrtnika ${ }^{42}$ što ukazuje na činjenicu da je jedan od razloga što se industrija u Osijeku do tada sporo razvijala žestoki otpor obrtnika koji su, udruženi u cehove, promovirali svoje proizvode i okupirali tržište. Međutim, 1872. godine ukidaju se cehovi te se obrtnicima daje veća sloboda. ${ }^{43}$ Unatoč tomu, moć obrtnika slabi u korist industrijalaca i oni se proletariziraju. U Osijeku je tada zaposlen velik broj radnika, primjerice tvornica žigica Adama pl. Reisnera, osnovana 1856. godine, upošljavala je 317 radnika. ${ }^{44}$ Ivo Mažuran pruža kronološki pregled broja zaposlenih te za 1890. godinu navodi podatke o 5 tvornica s 235 zaposlenih, 1900. 14 tvornica sa 697 zaposlenih, a 1910. 25 poduzeća s 2057 radnika. ${ }^{45} \mathrm{~S}$ njim se slaže Zlata Živaković-Kerže koja donosi podatak da je prije samoga rata industrija u Osijeku zapošljavala preko 2000 radnika. ${ }^{46}$ Radništvo je u Osijeku, kao i u ostatku Europe na prijelazu stoljeća, bilo u teškom položaju i radilo u neljudskim uvjetima. Radno vrijeme u osječkim tvornicama bilo je između 10 i 16 sati dnevno, a uređeno je Obrtnim zakonom iz 1884. godine. ${ }^{47} \mathrm{U}$ Osječkoj pivovari

40 Mažuran et al., Povijest Osijeka: Sv. 2, 153., Luka Pejić, Historija klasičnog anarhizma u Hrvatskoj: fragmenti subverzije, Zagreb 2016., 59.

41 Pejić, Historija klasičnog anarhizma, 64.

42 Plevnik, Stari Osijek, 135.

43 Sršan, Povijest Osijeka, 75., Plevnik, Stari Osijek, 135, Živaković Kerže, S tradicionalnih na nove puteve, 45.

44 Sršan, Povijest Osijeka, 71.

45 Mažuran et al., Od turskog do suvremenog Osijeka, 153.

46 Zlata Živaković-Kerže, „Multietničke značajke demografskih kretanja Osijeka i okolice na prijelazu iz 19. u 20. stoljeće“, Časopis za suvremenu povijest 33 (2001), br. 2: 484.

47 Pejić, Historija klasičnog anarhizma, 68.: Djeca od dvanaest do četrnaest godina smjela su raditi najviše 10, a ona od četrnaest godina do 12 sati na dan; radnice su imale slobodno 4 tjedna nakon porođaja; a načelni radni dan nije smio početi prije 5 sati ujutro, niti se produžiti nakon 21 sat navečer 
vlasnika Caetana Seppera radni je dan trajao od 5 sati ujutro do 21 sat navečer uz dva sata stanke. ${ }^{48}$ Česte su bile i nesreće na poslu kao ona u Reisnerovoj tvornici žigica iz 1897. godine kada je strojara Baumholzera (31 god.) zahvatio remen od mašine i odrubio mu glavu. ${ }^{49}$ Obrtni red donesen 1859. godine trebao je osigurati pružanje pomoći bolesnim radnicima u poduzećima koja su zapošljavala više od dvadeset radnika, no taj se zakon nije poštovao te su se radnici najčešće o svom trošku liječili u slučaju bolesti i nesreća. ${ }^{50}$

Osječko radništvo naseljavalo je uglavnom periferna radnička gradska naselja uz prometne putove ili u blizini industrijskih objekata. Domovi mnogih radnika tada su se nalazili u Gornjem gradu, ${ }^{51}$ preko puta željezničke pruge. Prema regulatornoj osnovi za grad Osijek iz 1912. godine, južno od željezničke pruge, što je tada bila nenaseljena periferija grada, predviđena je izgradnja industrijske zone koja bi bila blizu radničkim domovima. ${ }^{52}$ Predvodnik radničkoga pokreta u Osijeku, Dragutin Trauenheim, 17. veljače 1895. godine u gornjogradskoj pivovari govori:

„Druga vrst bezposlica muči se da posla dobije, da privredi toliko da on i obitelj od gladi neumre... Mi radnici nemožemo posla dobiti, djeca naša pala su u tifus od gladi, žene nam stenju u težkoj bolesti a nesmiljeni stanodavac tjera nas u sred zime iz stana jer smo sa nekoliko mjesecih plaćanjem stanarine zaostali... Vidimo velik broj siromašne djece da idu sada u ljutoj zimi u ljetnoj odjeći u školu. U školi vlada zagušljiv zrak jer neima ventilacije, kadkad lože furunu tako da se djeca blizu peći znoje kadkad sva strepe od zime... koji nema dosta moralne jakosti postane zločincem, krade da si djecu nahrani... I ja sam - ne stidim

48 Pejić, Historija klasičnog anarhizma, 67.

49 Darko Benašić i Ivan Gašparac. „Adam Reisner i tvornica šibica - prototip osječke industrije“, U: Osječki generalni štrajk iz 1905. godine, ur. Denis Detling et all, Osijek 2015., 12.

50 Branimir Križanec i Dražen Orkić, „Razvoj radničkog pokreta u Osijeku do 1905. godine“, U: Osječki generalni štrajk iz 105. godine, ur. Denis Detling et all., Osijek 2015.: Većinom su bili osigurani kod humanitarnih i osiguravajućih društava. Paromlin Slavonija istaknut je kao jedino postrojenje koje je pokrivalo troškove bolničke opskrbe tijekom 28 dana. Križanec i Orkić, „Razvoj radničkog pokreta“, 19., Živaković-Kerže, S tradicionalnih na nove puteve, 51., Mažuran et al., Od turskog do suvremenog Osijeka, 161.: Životni uvjeti poboljšali se tek 1891. godine stupanjem na snagu Zakona o nedjeljnom odmoru i Zakona o okružnim blagajnama koji je pokrivalo osiguranje velikom broju radnika

51 Luka Pejić, „Kriminalni i represivni sustav u Osijeku na prijelazu iz 19. u 20. stoljeće promatran kroz elemente biopolitike i socijalne povijesti“, Scrinia Slavonica 15 (2015), br. 1: 163., Josip Bradarić i Mate Ljubas, „Razvoj osječke industrije od 1890. do 1905. godine“, U: Osječki generalni štrajk iz 1905. godine, ur. Denis Detling et all., Osijek 2015., 5.

Jukić i Pegan, Prostorni i urbanistički razvoj, 33. 
se kazati - išao prosjačiti, ali od gladi jer krasti nemogu... Ja od Božića nisam više zaslužio od 17 fr. a imam 5 djece i bolestnu ženu... Diete od 7 godina života svoga kapital upregne da mu radi da mu hasnu vuče, neštedi ni otca mu ni mater upregne braću i sestre“. ${ }^{53}$

Ovaj govor donosi pregled bijednoga stanja osječkoga radništva koje se nerijetko odavalo prosjačenju i kriminalu da bi preživjelo. ${ }^{54}$

\section{Radnički aktivizam}

S obzirom na broj tvornica i radnika u gradu, radništvo se ubrzo počelo organizirati i priklanjati socijalističko-sindikalnim idejama. U većini dostupne literature istaknuta su dva radnička udruženja, Radničko društvo iz 1867., na čijem je čelu bio inženjer Gustav Wagner, a cilj mu je bio ideološki-obrazovno djelovati, ${ }^{55}$ i Obrtničko-radničko društvo iz 1874. godine koje je bilo povezano i s Prvom Internacionalom. ${ }^{56}$ Osijek je time bio prvi grad s organiziranim radničkim pokretom u Hrvatskoj i Slavoniji. Nezadovoljstvo životnim uvjetima često je kulminirala štrajkovima, a prvi puta radnici su se pobunili 25. siječnja 1869. godine, kada štrajkaju užarijski šegrti. ${ }^{57}$ Vrhunac radničke aktivnosti u Osijeku je, prema Pejiću, 1880-tih i 1890-tih godina, kada u grad dolaze socijalistički agitatori iz susjednih zemalja i održavaju se razni sastanci. ${ }^{58}$ U travnju 1905. godine stolari iz tvornice Povischil i Kaiser započeli su štrajk u kojem su tražili povišicu plaće od $10 \%$ te smanjenje radnoga vremena na 10 sati. $^{59}$ Taj se štrajk proširio na većinu osječkih pogona i rezultirao višetjednim demonstracijama i fizičkim sukobima radnika, građana i redarstvenika. Pejić ističe broj od 4.500 radnika koji su štrajkali. ${ }^{60}$ Međutim, štrajk je neuspio, a nekolicina ljudi je i uhićena. Veliki

53 Pejić, „Kriminalni i represivni sustav“, 163-164.

54 Isto, 140.: Najbrojniji okrivljenici u osječkom zatvoru bili su radnici - zidari, sluge, krojači, pekari, postolari, bravari i stolari

55 Pejić, „Radnički pokret“, 38., Mažuran et al., Od turskog do suvremenog Osijeka, 153., Plevnik, Stari Osijek, 160., Sršan, Povijest Osijeka, 73.

56 Pejić, „Radnički pokret", 38.

57 Pejić, Historija klasičnog anarhizma, 65., Plevnik, Stari Osijek, 160.: Štrajkaši su zahtijevali povišenje plaće, a zbog štrajkanja i ometanja procesa proizvodnje vlasnik užarije u prijavi gradskom poglavarstvu nazvao ih je „silegijama i beguncima“

58 Isto, 69-72.: Pokušaji širenja socijalističkih i anarhističkih ideja nisu urodili plodom budući da je represivni aparat radio na suzbijanju mogućega djelovanja. To je vidljivo u brojnim izmijenjenim pismima između osječkih gradonačelnika, bogatih uglednika i bana koji su bilježili dolazak bilo kojega potencijalnog revolucionara na područje

59 Isto, 76.

60 Isto, 78. 
osječki štrajk iz 1905. godine hrvatska historiografija bilježi kao prvi generalni štrajk u Hrvatskoj. Tiskarski aktivni postali su tek 1907. godine kada su započeli izdavati radničke novine „Volksrecht" (Pravo naroda). ${ }^{61}$ Do tada je među radništvom kružila štampa iz drugih krajeva. Prvi maj osječki su radnici prvi puta organizirano proslavili 1893. godine kada je mala povorka prošetala centrom grada i nastavila slavlje u gostionici. ${ }^{62}$ Kasnije su proslave uključivale veći broj radnika i parole sa zahtjevima poput skraćivanja radnoga vremena. Godine 1907. sudjelovalo je 5.000 ljudi te su se pjevale radničke pjesme na četirima jezicima. ${ }^{63}$

\section{Marginalne skupine}

Pojam marginalizacije vezan je uz dihotomiju između centra i periferije određenoga vrijednosnog sustava. ${ }^{64}$ Centar je prema tome ključan i sve što on obuhvaća smatra se uobičajenim obilježjima, dok je sve što je van centra, odnosno na periferiji, sporedno, drugačije i nevažno. Marginalizacija može biti provođena na ekonomskoj, prostornoj, kulturnoj i političkoj osnovi. Primjerice, prostitutke su marginalizirane na vrijednosnoj osnovi njihova bavljenja „nemoralnim poslovima“, dok su prosjaci marginalizirani ponajviše prostorno i ekonomski budući da nemaju stalno mjesto prebivališta te se uzdržavaju novcem koji dobiju od prosjačenja. Marginalizirane skupine izložene su, zbog nekih svojih karakteristika, represivnom aparatu vlasti. U gradu Osijeku u razdoblju od 1868. do 1914. godine u marginalne skupine možemo ubrojiti prostitutke, Rome, prosjake, siromahe, siročad i Židove.

\section{Prostitutke}

„Najstariji zanat u povijesti“ kojim „ženska koja svojim tijelom za novac bludni život tjera“, 65 prostitucija, postaje u 19. stoljeću, kako navodi Pejić, „pravi sociološki fenomen“.66 Prostitucija se zakonski regulira, a prostitutke se evidentiraju i posebna pažnja posvećena je održavanju

61 Pejić, „Radnički pokret u Osijeku (1867.-1920.)“, Essehist 2 (2010), br. 2: 42., Plevnik, Stari Osijek, 162.

62 Plevnik, Stari Osijek, 162.

63 Pejić, Historija klasičnog anarhizma, 69., Plevnik, Stari Osijek, 162.

64 Zoran Šućur, „Romi kao marginalna skupina“, Društvena istraživanja 9 (2000), br. 2-3: 212.

65 Pejić, „Kriminalni i represivni sustav“, 153.: Kako je prema Pravilniku o uređenju i nadziranju prostitucije u slobodnom i kraljevskom gradu Osieku iz 1896. godine utvrđen pojam „bludnice“

66 Pejić, „Kriminalni i represivni sustav“, 149. 
njihova zdravlja te su bile podvrgnute redovitim medicinskim pregledima. U Hrvatskoj i Slavoniji, pitanje prostitucije bilo je uređeno Kaznenim zakonom iz 1852. godine prema kojemu je nadziranje prostitucije prepušteno lokalnom redarstvu. ${ }^{67}$ Osječko je poglavarstvo evidentiralo i zakonski reguliralo prostituciju te je sačuvan popis bludnica iz 1886. godine koji sadrži listu s imenima devet osječkih bludilišta, u kojima je radilo oko 120 registriranih prostitutki. ${ }^{68}$ Neka od navedenih bludilišta su: „Crvena lampa“, „Kod Toše“ („Zum Toscho“), „Vienac“, „Kod crvene čizme" itd. Pravilnik o uređenju i nadziranju prostitucije u slobodnom i kraljevskom gradu Osieku nastao je 1896. godine te utvrđuje postupak registracije prostitutki, lokacije bordela (ne u blizini crkvi, bogomolja, učiona i javnih ureda), dob prostitutki i ostale odredbe, primjerice radno vrijeme bordela ili obilježja bordela (na bludilištima moraju cijelu noć gorjeti svjetiljke, zastori moraju biti spušteni...). ${ }^{69}$ Prostitutke je svaki dan morala pregledati vlasnica kuće, a liječnik dva puta tjedno zbog raširenosti sifilisa i drugih bolesti. Zbog rasta broja javnih kuća, širenja spolnih bolesti i trgovine bijelim robljem, Zemaljska vlada 1911. godine izdaje stroži pravilnik o bludilištima. ${ }^{70}$ Iste godine izdan je i Pravilnik za bludilišta u slobodnom i kraljevskom gradu Osijeku koji donosi nekoliko promjena u odnosu na pravilnik iz 1896. godine. Primjerice, o broju bludilišta i bludnica odlučivalo je Gradsko poglavarstvo dok je prije broj bludilišta bio ograničen od 3 do $15 .^{71}$

\section{Romi}

Prava domaćih, odnosno hrvatsko-slavonskih Roma, ${ }^{72}$ bila su uređena općim propisima i nekim posebnim propisima (leges speciales) koji su se odnosili posebno na Rome, a najčešće su se sastojali od uredbi kojima se pokušavala zaustaviti „skitnja“ Roma. ${ }^{73}$ Budući da se

67 Sergej Filipović, „Reguliranje prostitucije u Osijeku na prijelazu iz 19. u 20. stoljeće: Pravilnik o urešenju i nadziranju prostitucije iz 1896. i Pravilnik za bludilišta iz 1911." Scrinia Slavonica 14 (2014), br. 1: 145., Pejić, „Kriminalni i represivni sustav“, 152.

68 Pejić, „Kriminalni i represivni sustav“, 152.

69 Filipović, „Reguliranje prostitucije“, 146-149., Pejić, „Kriminalni i represivni sustav“, 153.

70 Isto, 150.

71 Isto, 151.

72 Ivan Kosnica, „Pravni položaj Roma u Hrvatskoj i Slavoniji od 1868. do 1919.“, Zbornik Pravnog fakulteta Sveučilišta u Rijeci 38 (2017), br. 2: 734.: U Hrvatskoj i Slavoniji njihovo je djelovanje regulirano na temelju njihova statusa koji su ostvarili kao strani ili kao domaći Romi

Isto, 736-737. 
u literaturi ne spominju specifični podaci o romskom stanovništvu u Osijeku, kao prilog pretpostavci da su Romi bili prisutni i u Osijeku, navest ćemo razmišljanja nadvojvode Josipa o Romima, koje 1894. godine prenosi Vjesnik Županije virovitičke, i nekoliko praktičnih savjeta „protiv Cigana“ koje spomenuti Vjesnik tiska 1904. godine. ${ }^{74}$ Iz prvoga članka koji govori o naseljavanju grupa Cigana ondje gdje treba radnika, što se može smatrati jednim od rješenja tzv. „ciganskog pitanja“ za koje Pejić navodi da se o njemu raspravljalo u visokim političkim krugovima, evidentno je da vlast u Hrvatskoj i Slavoniji nije znala što bi s njima. Nadalje, prvi članak potvrđuje određene stereotipe o Romima, primjerice da nisu „prijatelji čistoće“ i da su „loši gazde sa novcima“" „Praktični savjeti“ iz drugoga članka preporučuju čitateljstvu da ne puštaju Ciganina u dvorište ni u blizinu pašnjaka jer truju životinje. ${ }^{76}$ Većina podataka koje smo prikupili o Romima sadrže prizmu stereotipa ili se dotiču pitanja kriminalnoga ponašanja Roma. Pejić spominje da je Đuro Plavšić koji je uhićen zbog prosjačenja po zanimanju evidentiran kao „Ciganin“,77 a Vukelić navodi da je jedan od troje osječkih prosjaka koje je poznavalo svako dijete bio stari Ciganin. ${ }^{78}$

\section{Židovi}

Položaj osječkih Židova proistječe iz činjenice da su uživali punopravno građanstvo i mogli su posjedovati imovinu. ${ }^{79}$ Zlata ŽivakovićKerže navodi da su bili potpuno integrirani u osječko društvo zato što su većinom pripadali drugoj ili trećoj generaciji Židova koja se u 18. stoljeću doselila u Slavoniju. ${ }^{80}$ Prema tome, brojni su Židovi koji pripadaju višim slojevima društva te su vlasnici industrijskih postrojenja (paromlin „Union“ Oskara Weiszmayera i baruna Carla Leopola Pfeiffera), ugostiteljskih objekata („Grand Hotel“ Mavra Weingrubera),

74 Pejić, „Kriminalni i represivni sustav“, 159-160.

75 Vjesnik Županije virovitičke, 1894., III, 5 u Pejić, „Kriminalni i represivni sustav“, 159.

76 Isto, 160.

77 Pejić, „Kriminalni i represivni sustav“, 140.

78 Vukelić, Tragovi prošlosti, 67.

79 Ljiljana Dobrovšak, Židovi u Osijeku od doseljavanja do kraja Prvog svjetskog rata, Osijek 2013., 90-92.: Godine 1867. donesen je austrijski temeljni državni zakon kojim je proglašena građanska ravnopravnost Židova u Monarhiji. Osnova zakona o ravnopravnosti Židova prihvaćena je u Hrvatskom saboru 1873. godine te se Židovima kao građanima i vjernicima potvrdilo uživanje ravnopravnosti i slobode

80 Zlata Živaković-Kerže, „Udio Židova u gospodarstvu Osijeka u prvoj polovici 20. stoljeća“, Osječki zbornik 28 (2006), br. 20: 163. 
trgovci (veletrgovina Springer \& Petru Josipa Springera i Dragutina Petrua) ${ }^{81}$ itd. Ljiljana Dobrovšak navodi da je zlatno doba židovskih općina trajalo u razdoblju od 1880. do 1910. godine kada Osijek ima 28.505 stanovnika od kojih su 2.340 Židovi. ${ }^{82}$ Važno je istaknuti predsjednika gornjogradske Židovske bogoštovne općine, Hugoa Spitzera, koji je imao važnu ulogu u pokretanju cionističkoga pokreta u Hrvatskoj i Osijeku te predstavljao Židove Kraljevine Hrvatske i Slavonije na cionističkim kongresima. ${ }^{83}$ Njegov je rad rezultirao organiziranjem prvoga cionističkog kongresa u Osijeku i Hrvatskoj, 1904. godine. ${ }^{84}$ Unatoč povoljnim životnim uvjetima, Židovi su se i dalje morali nositi s predrasudama. Zapis Ljetopisa kapucinskoga samostana u Osijeku iz 1873. godine navodi da je Židov imenom Frank kupio kuću njihova susjeda Vuića te u stražnjem dijelu svoje kuće, unatoč protivljenju kapucina, sagradio kuću. U navedenoj je kući petnaest prozora koji gledaju prema dvorištu kapucina. Zbog toga su oni podigli zid iznad prozora Židova te na tom mjestu napravili sobu za osoblje. Rečeno je da su tako zatvorili prozore Židova i 1874. godine riješili problem, te ih Židov više ne gleda u dvorište. Ukupan trošak toga poteza iznosio je 1.300 forinti. ${ }^{85}$ Vilma Vukelić također navodi predrasude koje je susretala još u djetinjstvu, a čula ih je od druge djece. ${ }^{86}$ Kada su 1903. godine u Hrvatskoj i Slavoniji izbile protumađarske demonstracije, osječki su Židovi bili izloženi napadima zbog povezanosti s Mađarima, ${ }^{87}$ a njihov se položaj nastavio pogoršavati prodiranjem antisemitskoga raspoloženja iz drugih krajeva Monarhije.

\section{Skitnice, prosjaci i ostali}

Budući da je bio rastući industrijski grad, Osijek je vrvio siromasima i prosjacima te delinkventima raznih vrsta. U takvim uvjetima, u kojima dio stanovništva živi u potpunoj bijedi, kriminal je razgranat i ozbiljan problem. Primjerice, u Osijeku je tijekom 1902. godine uhićena

81 Dobrovšak, Židovi u Osijeku, 122-135.

82 Isto, 107.

83 Isto, 183.

84 Isto, 198.

85 Stjepan Sršan, Osječki ljetopisi: 1686.-1945., Osijek 1993., 336.

86 Vukelić, Tragovi prošlosti, 63.

87 Dobrovšak, Židov u Osijeku, 182-186.: Na izborima 1898. godine podržali su režimsku stranku „mađarona“ te se dio njih se smatrao Mađarima 
1941 osoba, a iz grada je protjerano 625 ljudi. ${ }^{88}$ Pejić navodi velik broj različitih vrsta zločina u Osijeku te njihove posljedice. Redom nabraja: ubojicu Ivana Bošnjaka, već spomenutoga prosjaka Đuru Plavšića, Johana Perca, uhićenoga zbog prosjačenja i besposlenosti, bratoubojicu Matu Abramovića, pedofila i silovatelja Iliju Holupa, itd. ${ }^{89}$ Nadalje, vlasti su odredile jasne propise prema kojima je prosjačenje i besposličarenje smatrano kriminalnim radnjama i kažnjavano, a Pejić zaključuje da su „u Osijeku na prijelazu stoljeća gotovo svakodnevno kažnjavani pojedinci zbog prosjačenja ili besposlenosti“.90 U veljači 1903. godine djeca u dobi od osam do dvanaest godina, koja su došla iz Đakova te su u Osijeku trebala naći posao, uhićena su zbog prosjačenja. Po dolasku ih je jedan muškarac usmjerio na prosjačenje u Donjem gradu. Počinitelj je uhićen, a djeca su dana na zanat kod privatnika. ${ }^{91} \mathrm{O}$ velikom broju siromaha, siročadi i potrebitih svjedoči postojanje sirotišta te sačuvani arhivski spisi gradskoga poglavarstva o mnogobrojnim zakladama koje su osnovane i djelovale su u razdoblju od 1868. do 1914. godine. ${ }^{92}$

\section{Etničke i druge značajke stanovništva Osijeka}

Početkom 1868. godine, Osijek je već bio multietnički grad. Velik broj trgovačko-obrtničkih djelatnosti obnašali su Nijemci i Židovi. Nadalje, Mađari dolaze u grad privučeni jeftinom zemljom. ${ }^{93}$ Iako je Osijek povijesno i politički grad Kraljevine Hrvatske i Slavonije, od brojnih naroda koji su se doseljavali na prostoru grada, najbrojniji su bili Nijemci, čiji se broj učetverostručio do 1900. godine. Međutim, broj Nijemaca se nakon toga smanjuje te oni gube status najbrojnijega naroda u gradu. To je vidljivo u popisu iz 1910. godine kada je broj Hrvata u gradu dosegao 12 808, tj. 37.7\% ukupnoga stanovništva, a Nijemaca 12 381, ili 36.4\% stanovništva. ${ }^{94} \mathrm{~S}$ obzirom na razvoj hrvatskoga

88 Pejić, „Kriminalni i represivni sustav“, 142.

89 Isto, $140-145$.

90 Isto, 164.

91 Isto, 165.

92 Jukić i Pegan, Prostorni i urbanistički razvoj, 30., Sršan, Osječki ljetopisi, 206.: Primjerice Svirčević Paulina za gr. ubožište, Reisner pl. Adam za potporu radnika, Franje Josipa za siromahe, Jäger Lovro za žensko sirotište, Normann grofica Marijana za siromahe (Jelaš, Gradsko poglavarstvo, 86-87.) Godine 1870. izgrađeno je sirotište u Strossmayerovoj ulici. Spomenuto sirotište preuzele su 1881. godine Kćeri milosrđa sv. Vinka Paulskog

Živaković Kerže, Urbanizacija i promet, 77-78.

94 Živaković-Kerže, „Multietničke značajke“, 481. 
identiteta, te Osijeka kao hrvatskoga grada, može se zaključiti kako se povećao broj stanovnika koji su se izjašnjavali kao Hrvati, ne samo zato što su imali veći prirast ili broj migranata, već i zbog određenih političko-ekonomskih faktora zbog kojih dolazi do jačanja nacionalne svijesti. ${ }^{95}$ Što se tiče Mađara, njihov se ukupni udio u broju stanovnika udvostručio (sa 6.3\% na 12.7\%). Razlog tomu je promađarska politika, posebice u vrijeme banovanja Khuena-Héderváryja (1883. - 1903.). U grad se doseljavaju brojni birokrati i činovnici iz Mađarske te dolazi do pojačane promocije mađarske kulture i jezika. Židovi i Srbi također bilježe porast stanovništva u ovom razdoblju te, unatoč jednoznamenkastom postotku u ukupnom broju stanovništva Osijeka, oba naroda ostvaruju znatan utjecaj na osječkoj gospodarskoj i kulturnoj sceni.

\begin{tabular}{|c|c|}
\hline \multicolumn{2}{|c|}{$\begin{array}{c}\text { Broj stanovnika Osijeka } \\
\text { tijekom godina }\end{array}$} \\
\hline 1869. & $19942 / 19281$ \\
1880. & $20356 / 19809$ \\
1890. & $22195 / 21547$ \\
1900. & $27383 / 26769$ \\
1910. & $34014 / 33337$ \\
\hline
\end{tabular}

Tablica 1. Prikaz broja stanovnika Osijeka tijekom godina ${ }^{96}$

Prema navedenoj tablici, vidimo konstantan porast stanovništva u periodu između 1869. i 1910. godine. Kada bi se u obzir uzeo i popis iz 1857. godine, kada je prema popisu u gradu živjelo 16145 stanovnika, moglo bi se zaključiti kako se broj stanovnika u Osijeku više nego udvostručio. ${ }^{97}$ Udio prigradskih naselja u ukupnom stanovništvu Osijeka polagano se smanjuje u ovom razdoblju (sa $22.5 \%$ 1869. na oko $17 \%$ 1910. godine), što pokazuje značajnu centralizaciju stanovništva na području grada. ${ }^{98}$ Višejezičnost je još jedna bitna karakteristika tadašnjega Osijeka. U ovom razdoblju latinski je već izgubio status kao politički i intelektualni jezik, te ustupljuje mjesto njemačkom i hrvatskom. Iz popisa stanovništva 1880. godine vidljivo je kako je Osijek hrvat-

95 Živaković-Kerže, „Multietničke značajke“, 481.

96 Verica Andraković i Marijan Jukić, „Dinamika stanovništva grada Osijeka od 1857. do 2001. godine“, Anali zavoda za znanstveni i umjetnički rad u Osijeku 25 (2009), 31., Živaković-Kerže, „Multietničke značajke“, 480.

97 Andraković, Jukić. „Dinamika stanovništva“, 31.

98 Isto, 33. 
ski grad s najnižim postotkom govornika hrvatskoga jezika (41.1\%), dok je njemački kao materinji jezik navelo gotovo pola stanovništva (49.3\%). ${ }^{99} \mathrm{Na}$ prostoru grada znatnije su bili zastupljeni i srpski, te mađarski jezik, ali njemački jezik će do Prvoga svjetskog rata ostati dominantan jezik na kulturološko-trgovačkoj sceni grada.

\section{Građanske aktivnosti i okupljališta}

\section{Djelovanje udruga, zadruga i društava}

Utjecaj koji je gospodarski i tehnološki napredak imao na gotovo sve sfere života, razlog je impresivnom razvoju civilnoga društva u Osijeku od 1868. do 1914. godine. Osječka kulturno-umjetnička scena obogaćena je brojnim novim udrugama, zadrugama i društvima koje su djelovale u javnom životu te, zahvaljujući njima, danas možemo pratiti duh ondašnjega grada. Osim kulturno-umjetničkih, osnivana su i društva koja su zastupala i promovirala određene djelatnosti, poput liječničkih, pravnih i odvjetničkih društava. Osnivanjem dobrotvornih i humanitarnih udruženja poput Dobrovoljnoga vatrogasnog društva (1872.) ili Crvenoga križa (1887.) naznačeno je postojanje kulture solidarnosti u gradu. U periodu u kojemu je većina stanovništva još uvijek nepismena, u Osijeku se razvija bogata kultura čitanja. Primjerice, 1862. godine osnovana je Narodna čitaonica, a vrijedi spomenuti i čitaonice osnovane u Donjem (1884.) i Gornjem gradu (1893.). Godine 1877. osnovan je Muzej Slavonije što svjedoči o rađanju potrebe za očuvanjem povijesti. Klub hrvatskih književnika i umjetnika osniva se 1909. godine, a cilj mu je bio propagiranje i unaprjeđenje hrvatske knjige i jezika. ${ }^{100}$

\section{Slobodno vrijeme (glazba, umjetnost, sport)}

Glazbeni život Osijeka bio je vrlo bogat, što potvrđuje postojanje brojnih glazbenih društava, od kojih je većina začeta upravo u ovom periodu. Već sredinom stoljeća u Osijeku postoje crkvena i svjetovna pjevačka društva, a najistaknutije bilo je Osječko pjevačko društvo, osnovano 1858. godine. Sredinom stoljeća Osijek postaje tamburaško središte Hrvatske i okolice, a na čelu tamburaške glazbene scene nala-

99 Živaković Kerže, „Multietničke značajke“, 485.

100 Plevnik, Stari Osijek, 114. 
zi se Pajo Kolarić. Istaknuti osječki glazbenici su i Franjo Kuhač, Franjo Krežma, Adolf Schiller, Helena Ćordašić i brojni drugi koji su svojim zaslugama stavili Osijek na glazbenu kartu Europe. ${ }^{101}$

Ni filmska industrija nije zaobišla Osijek te u kratkom periodu prije rata u Osijeku gostuju brojni kinematografi, a 1910. godine osnovan je prvi stalni kinematograf. Vrhunac razvoja predratne kinematografije bila je izgradnja kina „Urania“ 1912. godine u Gornjem gradu. Važno je spomenuti i osječku kazališnu scenu koja je 1866. godine dobila zgradu budućega Hrvatskog narodnog kazališta u Osijeku, a u vrijeme izgradnje služila je za putujuće kazališne družine. Tek 1907. godine osniva se Kazališno društvo čiji je prvi predsjednik bio dr. Ante Pinterović.

Osječki je sport bio iznimno razvijen u ovom razdoblju te su osnovani brojni novi klubovi koji su pokrivali gotovo sve sportove. Primjerice 1876. godine osnovan je „Klizački klub Osijek“ te je iste godine napravljeno i klizalište. Tenis se u gradu igra od 1890. godine kada je osnovan „Lawn Tennis Club“. ${ }^{102}$ U Osijeku tada djeluju i brojni veslački, a tek od 1906. godine i nogometni klubovi. Važno je spomenuti i osnivanje „Hrvatskog sokola“ 1865. godine koji je do početka rata bio drugo najjače gimnastičarsko društvo u Hrvatskoj. ${ }^{103}$

\section{Gradska okupljališta}

Krčme, kavane, gostionice, kavotočja i kupališta pružali su građanima Osijeka mnoštvo izbora pri odlučivanju na koji će način provesti slobodno vrijeme. Broj ugostiteljskih objekata u gradu bio je, statutom iz 1886. godine, točno definiran na šest svratišta, šezdeset gostionica, dvadeset krčmi, deset pivovara, osam rakijašnica, dvanaest kavana i dvanaest kavotočja. ${ }^{104}$ Zanimljivo je istaknuti razliku između kavana i kavotočja. Naime, u kavanama mora biti barem jedan biljar dok je u kavotočjama zabranjen „biljar, kartanje i ine igre“ (slika 2.). ${ }^{105}$ Bitno je istaknuti važnost gostionica za toponimiju grada. Gostionica koja bi se nalazila u nekoj ulici, davala bi toj ulici ime te je tako gostioni-

\footnotetext{
101 Plevnik, Stari Osijek, 119.

102 Isto, 166.

103 Isto, 173.

104 HR-DAOS-6, 5905 knj., „Statut za obrte baveći se držanjem svratištah, gostionicah, krčam, pivovarah, rakijašnicah, kavanah i kavotočjak“: „Kavotočjem se smatra posao, gdje se dobiva kave, čaja, čokolade i spadajućega k njim peciva“

105 Isto
} 
ca Tri ruže dala ime Ružinoj ulici. ${ }^{106}$ Krčme i gostionice bile su poradi ponašanja svojih gostiju na zlom glasu. Pejić prenosi članak Vjesnika Županije virovitičke iz 1896. godine u kojem stoji da se mladi u danima oko blagdana i nedjeljama skupljaju u krčmama te ondje „halabuču, plešu i natežu se na sve moguće mrske i nepristojne načine“. Nadalje, kad padne mrak, većina ih se do kasnih sati po mjestu „skiće, klatari, vrištri, fućka, urliče i lupa po plotovima" tako da ometaju ostale, umorne građane. ${ }^{107}$ Gostionice su također bile opasne kao mjesta u kojima su se širile razne socijalističke i ine ideje. Primjerice, krčma Adolfa Bissera služila je radnicima tvornice Povischil i Kaiser kao okupljalište tijekom štrajka 1905. godine. ${ }^{108}$

Otmjeniji građani okupljali su se u kavanama u kojima se moglo naručiti razne inačice kave, ${ }^{109}$ a vlasnici kavana često su priređivali i filmske projekcije i zabave. Poznatije kavane bile su kavana Casino u Županijskoj ulici, kavana Central i kavana Royal. ${ }^{110}$ Kavane su posjećivali bogati trgovci i industrijalci, ugledni građani, glumci, odvjetnici i liječnici te su one, kao i krčme, imale dvojaku ulogu društvenih i poslovnih mjesta u kojima su se sklapali razni ugovori i dogovori. Balovi i plesnjaci također su bili rezervirani za više i srednje slojeve, a održavali su se u posebnim plesnim dvoranama. Zanimljivo je spomenuti zainteresiranost koju su Osječani pokazali za cirkuske predstave kada se pod velikim šatorom poznatoga cirkusa Barnum i Bailey okupilo 20.000 ljudi iz grada i okolice, te za vrijeme predstave gostionice, trgovine i uredi nisu radili. ${ }^{111}$

106 Ivan Horvat, „Noćni život i zabava u Osijeku na prijelazu 20. stoljeća“, Essehist 2 (2010), br. 2: 26., Pejić, „Kriminalni i represivni sustav“, 155., Aleksić i Kovačević, „Gostionice i birtije", 30.

107 Pejić, „Kriminalni i represivni sustav“, 156.

108 Petrica Aleksić i Andrea Kovačević, „Gostionice i birtije - sastajališta osječkog radništva“, U: Osječki generalni štrajk iz 1905. godine, ur. Denis Detling et all., Osijek 2015., 31.

109 Horvat, „Noćni život“, 27., Vukelić, Tragovi prošlosti, 84.

110 Aleksić i Kovačević, „Gostionice i birtije“, 29., Horvat, „Noćni život“, 27.

111 Horvat, „Noćni život“, 30.: Osijek su, na prijelazu stoljeća, posjetili Circus Articelli, Cirkusa Pikard i Cirkusa Renlov, a Osječane je posebno oduševila Montenegrova Menažerija u kojoj su mogli vidjeti velike zmije, 18 lavova, 6 divljih bengalskih jaguara, morske medvjede i srebrne lavove. 


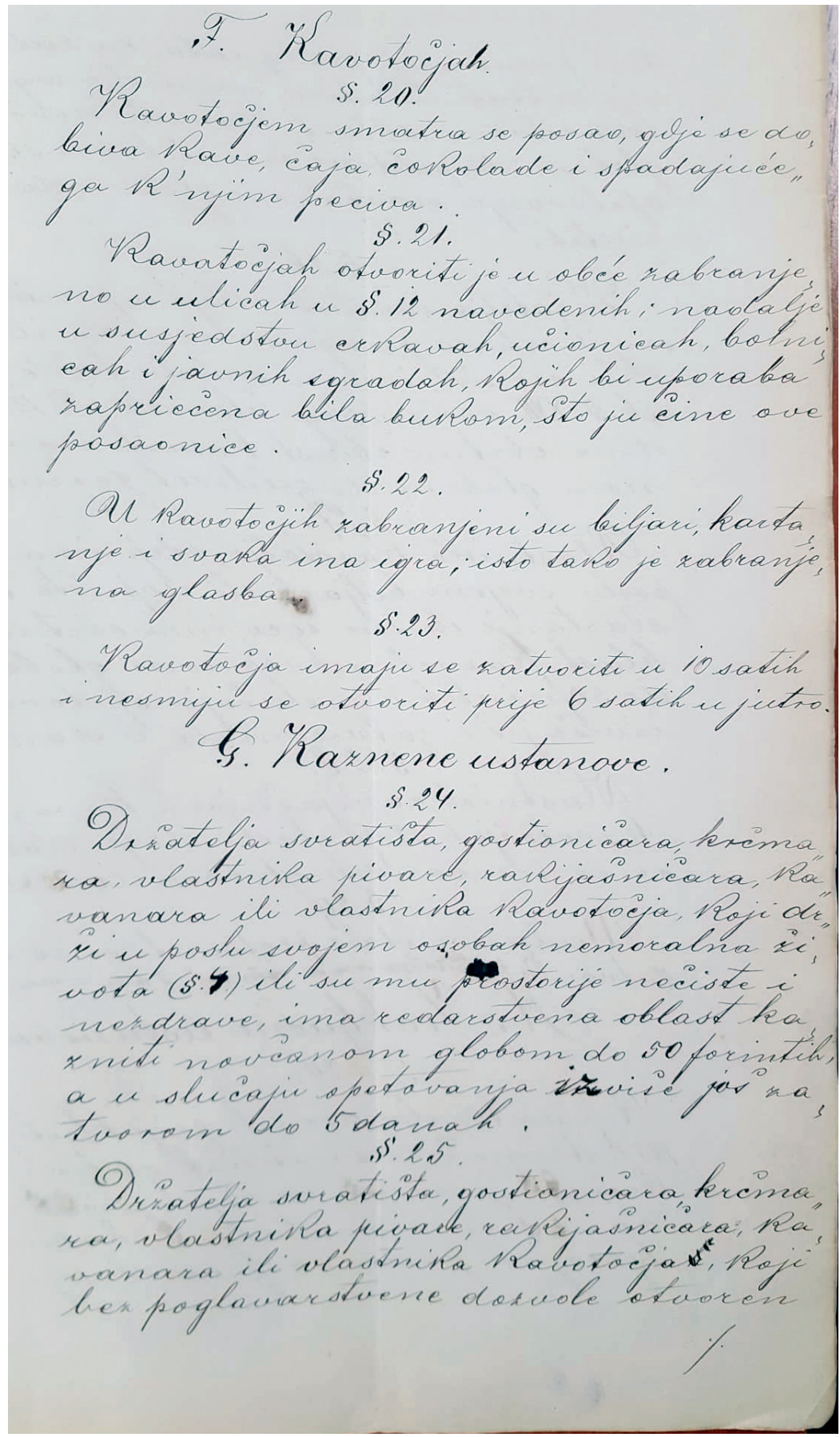

Slika 3. Stranica iz statuta Gradskoga poglavarstva iz 1886. godine $e^{112}$

112 HR-DAOS-6, 5905 knj. „Statut za obrte“. 


\section{Zaključak}

Na temelju izloženih podataka možemo zaključiti da je Osijek u drugoj polovici 19. stoljeća slijedio industrijske i urbane trendove karakteristične za ostale europske metropole. Stalan rast broja stanovništva svjedoči ponajviše o doseljavanjima iz okolnih područja, zatim i okolnih zemalja, posebice Njemačke i Mađarske. Kao jedno urbano središte, Osijek postaje privlačan trgovcima, industrijalcima i bankarima te se u njemu razvija industrija, trgovina i novčarstvo. Viši slojevi društva koji obavljaju spomenute poslove ostavljaju svoj pečat na gradu podizanjem raskošnih kuća, poslovnih zgrada i prostora. Oni upravljaju osječkim kulturnim i političkim životom. Srednji slojevi najmanje su zastupljeni u literaturi, stoga se o njima ne mogu donositi sigurni zaključci. U literaturi je istaknuta dihotomija između materijalnoga stanja viših i nižih slojeva, no pojavljuju se i podaci o srednjem sloju koji je još tražio svoje mjesto u društvu. 0 urbanom rastu i industrijskom razvoju Osijeka svjedoči i sve veći broj tvornica i radnika. Predugo radno vrijeme i male plaće ubrzali su širenje socijalističkih ideja te nagnale radnike na borbu za poboljšanje svoga položaja koji su nerijetko pokušali popraviti kriminalom. Stajalište da je Osijek bio progresivan industrijski grad potkrepljuje činjenica da je u njemu nastala prva radnička organizacija u hrvatskim zemljama te održan prvi generalni štrajk. Također, najsiromašnije radništvo dijeli društveni status s prosjacima i skitnicama koji su često pritvarani. Na rubovima društva nalaze se i prostitutke, čiju djelatnost grad iskorištava zbog oporezivanja te Romi koji se spominju kao prosjaci i zatvorenici. Iako obnašaju razne visoke dužnosti u gradu, Židovi su i dalje izloženi predrasudama, što se pogoršava početkom dvadesetoga stoljeća prodiranjem antisemitizma iz ostalih krajeva Monarhije. Zanimljivo je istaknuti da unatoč, ili zahvaljujući, svojem multinacionalnom karakteru, Osijek tolerira i prihvaća svakoga te raste i razvija se neometano sve dok se politička situacija ne zamrsi početkom 20. stoljeća. Također, u gradu su osnivane mnoge udruge, zadruge i udruženja te su se stanovnici Osijeka počeli češće baviti sportom i uživati u glazbenim i umjetničkim sadržajima koje grad nudi. Krčme, gostionice i kavane mjesta su, ne samo zabave, nego i poslovnih i političkih dogovora, a osječki građani zaista postaju kozmopoliti, stanovnici jednoga urbano zaokruženog te industrijski i društveno razvijenoga grada. 


\section{Bibliografija}

\section{Knjige i članci:}

Aleksić, Petrica, Kovačević, Andrea. „Gostionice i birtije- sastajališta osječkog radništva“. U: Osječki generalni štrajk iz 1905. godine, ur. Denis Detling et al., 29-32. Osijek: Muzej Slavonije: Filozofski fakultet Osijek, 2015.

Andraković, Verica, Jukić, Marijan. „Dinamika stanovništva grada Osijeka od 1857. do 2001. godine“. Anali zavoda za znanstveni i umjetnički rad u Osijeku 25 (2009), 23-45.

Benašić, Darko, Gašparac, Ivan. „Adam Reisner i tvornica šibica - prototip osječke industrije“. U: Osječki generalni štrajk iz 1905. godine. ur. Denis Detling et al., 10-13. Osijek: Muzej Slavonije: Filozofski fakultet Osijek, 2015.

Bošković, Đorđe, Najcer Sabljak, Jasminka. „Likovna i rukopisna ostavština Ladislava grofa Pejačevića iz Retfale i Rume“. Scrinia Slavonica 18 (2018), br. 1: 129-174.

Božić-Drljača, Vesna, Jelaš, Danijel. Život u Osijeku u okolnostima Prvog svjetskog rata. Osijek: Državni arhiv u Osijeku, 2014.

Bradarić, Josip, Ljubas, Mate. „Razvoj osječke industrije od 1890. do 1905. godine“. U: Osječki generalni štrajk iz 1905. godine. ur. Denis Detling et all., 5-9. Osijek: Muzej Slavonije: Filozofski fakultet Osijek, 2015.

Červenjak, Jelena, Živaković-Kerže, Zlata. „Modernizacijska kretanja i položaj žena u gradu Osijeku na prijelazu 19. u 20. stoljeće", Scrinia Slavonica 14 (2014), br. 1: 129-141.

Dobrovšak, Ljiljana. Židovi u Osijeku od doseljavanja do kraja Prvoga svjetskog rata, Osijek: Čarobni tim: Židovska općina, 2013.

Filipović, Sergej. „Reguliranje prostitucije u Osijeku na prijelazu iz 19. u 20. stoljeće: Pravilnik o uređenju i nadziranju prostitucije iz 1896. i Pravilnik za bludilišta iz 1911." Scrinia Slavonica 14 (2014), br. 1: 141-158.

Gross, Mirjana, Szabo, Agnesa. Prema hrvatskome građanskom društvu, Zagreb: Globus, 1992.

Hrvatska - Državni arhiv u Osijek, Osijek - „Statut za obrte baveći se držanjem svratištah, gostionicah, krčmah, pivovarah, rakijašnicah, kavanah i kavotočjah“ (HRDAOS-6, 5905 knjiga)

Horvat, Ivan. „Noćni život i zabava u Osijeku na prijelazu 20. stoljeća“. Essehist 2 (2010), br. 2: 26-31.

Ivanković, Grgur Marko. „Tvrđa na fotografijama i razglednicama“. U: Tvrđa u Osijeku, ur. Denis Detling,

70-74. Osijek: Muzej Slavonije, 2017.

Jelaš, Danijel. Gradsko poglavarstvo Osijek: serija: Predmetni spisi (1880 - 1945), Analitički inventar. Osijek: Državni arhiv u Osijeku, 2011.

Jukić, Tihomir, Pegan, Srečko. Prostorni i urbanistički razvoj Osijeka: kritika i prijedlozi. Zagreb: Arhitektonski fakultet, 2005.

Karaman, Igor, Privreda i društvo Hrvatske u 19. stoljeću. Zagreb: Školska knjiga, 1972.

Kosnica, Ivan. „Pravni položaj Roma u Hrvatskoj i Slavoniji od 1868. do 1918.“. Zbornik Pravnog fakulteta Sveučilišta u Rijeci 38 (2017), br. 2: 729-744.

Kričkić, Dino. „Povijest sporta u Osijeku“. Essehist 2 (2010), br. 2: 55-60.

Križanec, Branimir, Orkić, Dražen. „Razvoj radničkog pokreta u Osijeku do 1905. go- 
dine“. U: Osječki generalni štrajk iz 1905. godine. ur. Denis Detling et all., 16-20. Osijek: Muzej Slavonije: Filozofski fakultet Osijek, 2015.

Mažuran, Ive et al. Povijest Osijeka: Sv. 2: Od turskog do suvremenog Osijeka, Osijek; Zagreb: HAZU, Zavod za znanstveni rad: Poglavarstvo grada: Školska knjiga, 1996. Pejić, Luka. Historija klasičnog anarhizma u Hrvatskoj : fragmenti subverzije, Zagreb: DAF, 2016.

Pejić, Luka. „Kriminalni i represivni sustav u Osijeku na prijelazu iz 19. u 20. stoljeće promatran kroz elemente biopolitike i socijalne povijesti“, Scrinia Slavonica 15 (2015), br. 1: 133-174.

Pejić, Luka. „Radnički pokret u Osijeku (1867. - 1920.)“, Essehist 2 (2010), br. 2: 36-43. Plevnik, Božo. Stari Osijek, Osijek: Radničko sveučilište Božidar Maslarić, 1987.

Sršan, Stjepan. Osječki ljetopisi : 1686. - 1945., Osijek : Povijesni arhiv, 1993.

Sršan, Stjepan. Povijest Osijeka, Osijek: Povijesni arhiv u Osijeku, 1996.

Šućur, Zoran. „Romi kao marginalna skupina“, Društvena istraživanja 9 (2000), br. 2-3: 211-227.

Švajcer, Oto. „Pregled likovne umjetnosti u Osijeku u 19. stoljeću“. Osječki zbornik 22 (1979.), br. 1: 231-298.

Parsons, Talcott. Društva, Zagreb: Biblioteka August Cesarec, 1991.

Živaković Kerže, Zlata. „Multietničke značajke demografskih kretanja Osijeka i okolice na prijelazu iz 19. u 20. stoljeće“, Časopis za suvremenu povijest 33 (2001), br. 2: 475-491.

Živaković Kerže, Zlata, $S$ tradicionalnih na nove puteve: trgovina, obrt, industrija $i$ bankarske ustanove grada Osijeka na prijelazu stoljeća od godine 1868. do 1918. Zagreb: Hrvatski institut za povijest; Slavonski Brod: Podružnica za povijest Slavonije, Srijema i Baranje; Osijek: Društvo za hrvatsku povjesnicu, 1999.

Živaković-Kerže, Zlata. „Udio Židova u gospodarstvu Osijeka u prvoj polovici 20. stoljeća“. Osječki zbornik 28 (2006), br. 20: 161-169.

Živaković Kerže, Zlata. Urbanizacija i promet grada Osijeka na prijelazu stoljeća (1868. - 1918.), Osijek: Društvo za hrvatsku povjesnicu Osijek, 1996.

Vukelić, Vilma. Tragovi prošlosti. Zagreb: Nakladni zavod Matice hrvatske, 1994.

\section{Internetski izvori:}

http://www.enciklopedija.hr/natuknica.aspx?id=34445 (5. 4. 2019.)

https: / / hr.wikipedia.org/wiki /Peja\%C4\%8Devi\%C4\%87i\#-_Rumskoretfala\%C4\%8Dki (17.4. 2019.)

http://essekeri.hr/reisner-adam.html (6. 4. 2019.)

http://essekeri.hr/strossmayer-josip-juraj.html (6. 4. 2019.)

\section{Popis priloga}

Prilog 1: Slika 1. Karta i urbanistički plan (regulatorna osnova) Osijeka iz 1912. godine Hrvatska - Državni arhiv u Osijek, Osijek- Planovi grada i položajni nacrti grada Osijeka (HR-DAOS-495/IV, sig.1.5, mapa 48)

Prilog 2: Slika 2. Strossmayerova ulica 
http://rektorat.unios.hr/skup_2017/index.php?lah=1\&blt=9\&gal=stari_osijek (28. 4. 2019.)

Prilog 3: Tablica 1. Prikaz broja stanovnika Osijeka tijekom godina

Andraković, Verica, Jukić, Marijan. „Dinamika stanovništva grada Osijeka od 1857. do 2001. godine“. Anali zavoda za znanstveni i umjetnički rad u Osijeku 25 (2009), 31., Živaković Kerže, Zlata. „Multietničke značajke demografskih kretanja Osijeka i okolice na prijelazu iz 19. u 20. stoljeće“, Časopis za suvremenu povijest 33 (2001), br. 2: 480

Prilog 4: Slika 3. Stranica iz statuta Gradskog poglavarstva iz 1886., Hrvatska - Državni arhiv u Osijek, Osijek - „Statut za obrte baveći se držanjem svratištah, gostionicah, krčmah, pivovarah, rakijašnicah, kavanah i kavotočjah“ (HR-DAOS-6, 5905 knjiga)

\section{SUMMARY}

The article presents and analyses different aspects of Osijek's society in the period between the signing of the Croatian - Hungarian Settlement of 1868 and the start of World War I. in 1914. After a short overview of important infrastructural and construction projects in the said period, the authors devote the rest of the paper to examining the social classes of Osijek. Special attention is given to the working class and marginalized groups. Also mentioned is the multiethnic and multilingual aspect of the city, through which Osijek developed its identity. Finally, the article briefly mentions newly created clubs and organizations which showcased the growing social movement and activism among the citizenry. Likewise, by highlighting the sociocultural activity of citizens from all social classes, the vibrancy of Osijek in this period is fully shown.

Keywords: Osijek, society, modernization, social classes, working class, marginalized groups, ethnic characteristics, associations, gathering places 